Proc. Estonian Acad. Sci. Biol. Ecol., 2001, 50, 3, 194-199

\title{
LITTORAL ZONE RESEARCH IN THE NEVA ESTUARY (EASTERN GULF OF FINLAND): HISTORY AND PERSPECTIVES
}

\author{
Vadim E. PANOV, Sergey M. GOLUBKOV, and Marina I. ORLOVA \\ Zoological Institute of the Russian Academy of Sciences, Universitetskaya nab. 1, 199034 \\ St. Petersburg, Russia; gaas@zin.ru \\ Received 28 March 2001, in revised form 24 April 2001
}

\begin{abstract}
The history of littoral zone research in the Neva estuary, the largest estuary in the Baltic Sea, is described. Environmental problems, including effects of eutrophication and introductions of alien species, are discussed. A brief outline of future research is provided.
\end{abstract}

Key words: Gulf of Finland, Neva estuary, littoral zone, eutrophication, alien species, history of research.

The Neva estuary is the largest estuary in the Baltic Sea, located in the eastern Gulf of Finland. It has sustained a heavy impact from human activities, including discharges of treated and untreated wastewaters from point sources in St. Petersburg and intensive ship traffic. The Neva estuary consists of three main parts: Neva Bay (surface area $400 \mathrm{~km}^{2}$ ), and the inner and outer estuaries (total surface area of the last two parts about $3200 \mathrm{~km}^{2}$ ) (Pitkänen, 1991). Since the early 1980s freshwater Neva Bay has been separated from the brackish lower reaches of the estuary by a storm-surge barrier, which is still under construction (Fig. 1).

The coastal zone of the estuary is intensively exploited for recreation (specifically in the Resort District of St. Petersburg), sport and commercial fishing, military purposes, and various industrial uses including nuclear power and shipping. The coastal zone also receives discharges of treated and untreated wastewaters, occurring mainly in the lower Neva River and in Neva Bay. Heavy nutrient loading (eutrophication), mainly from point sources in the Neva River and the upper estuary, is currently the most serious environmental problem for the Neva estuary and adjacent parts of the eastern Gulf of Finland (Alimov et al., 1996; Leppänen et al., 1997). The introduction of alien species is an emerging issue for the Neva estuary (Alimov et al., 1998; Orlova et al., 1999b; Panov et al., 


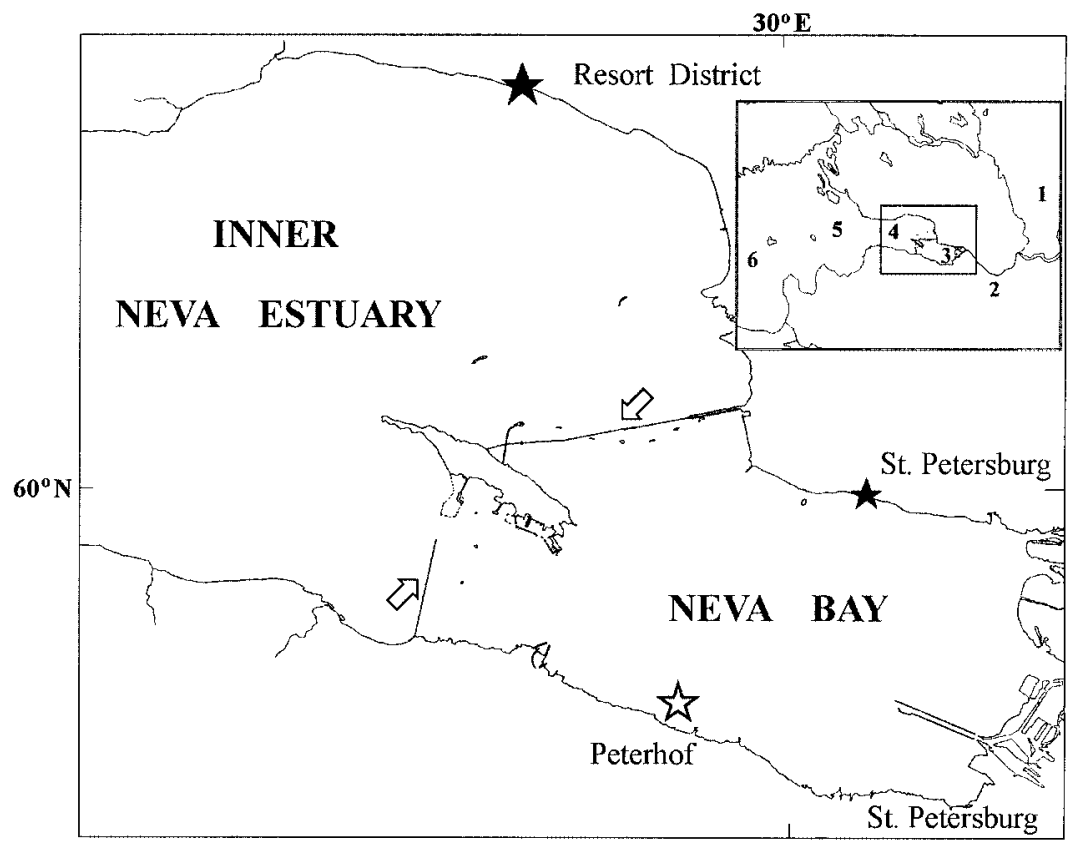

Fig. 1. The Neva estuary. 1, Lake Ladoga; 2, Neva River; 3, Neva Bay; 4, inner estuary; 5, outer estuary; 6, eastern Gulf of Finland. Large open asterisk indicates principal areas of littoral zone research in 1935-37, small filled asterisk in 1982-86, and large filled asterisk in 1998-2000. Arrows indicate the storm-surge barrier.

1999), and it should be considered very seriously, given the rapid development of the shipping industry in this area.

Early research and monitoring efforts, started at the beginning of the 1900s, focused on the open areas of the Neva estuary (reviewed by Finogenova et al., 1987 and Balushkina et al., 1996) despite the fact that eutrophication effects are much more obvious in the littoral zone (Panov et al., 1997; Orlova et al., 1999a). As a result of eutrophication, extensive macrophyte beds have developed along the shoreline in Neva Bay, and mats of filamentous green algae (mainly Cladophora glomerata) occur during summer in the exposed littoral zone of the inner estuary. Intensive growth of macrophyte beds and filamentous algae have caused deterioration of the environmental quality of nearshore recreational areas.

The first study of the estuary's littoral zone was conducted in 1935-37 by scientists of Leningrad State University (Anon., 1949). It included a detailed description of the structure of the macroinvertebrate community along one transect at the south shore of Neva Bay near Peterhof (Fig. 1). Almost 50 years later, in 1982-86, scientists from the Zoological Institute of the Russian Academy of Sciences initiated the first comprehensive studies of littoral communities in Neva Bay. During this period important background data on the structuralfunctional organization of littoral communities were obtained, including detailed 
descriptions of littoral macrophyte associations (Belavskaya, 1987; Korelyakova, 1997) and zoobenthic communities (Golubkov et al., 1987a), and a special study of production processes in macrophyte beds (Golubkov et al., 1987b). Detailed studies of invertebrate communities associated with aquatic plants were conducted during 1983-86 at one location on the northern shore of Neva Bay, and the main results were published in a book (Alimov, 1988).

The exposed littoral zone of the inner estuary was not studied until 1998, but occasional observations of the beaches in the St. Petersburg Resort District had revealed increasing development of algal mats as a result of severe eutrophication of the estuary (Shishkin et al., 1989). Subsequent studies of macrophyte associations in Neva Bay conducted in 1990 by Korelyakova (1997) showed an accelerating rate of growth of emergent macrophytes, which was attributed mainly to hydrological changes in the ecosystem after the construction of the storm-surge barrier. This study also showed deteriorating environmental quality in the nearshore habitats. As was further argued by Panov et al. (1997), the development of extensive macrophyte beds and mats of Cladophora in the estuary during recent decades indicated heavy eutrophication. Special research efforts are needed in order to obtain essential data on functional parameters of the littoral zone to support its management.

The first detailed study of the exposed littoral zone of the inner estuary was conducted by scientists from the Zoological Institute in 1998. This study focused on the environmental state assessment for the beaches in the St. Petersburg Resort District (Fig. 1), and for the first time provided recommendations for the organization of littoral zone monitoring (Orlova et al., 1999a). The study provided the first attempt to evaluate the main factors influencing the environmental quality within the Neva estuary littoral zone, including the development of Cladophora mats and effects of alien species such as zebra mussel (Dreissena polymorpha). The seasonal dynamics of Cladophora biomass in the shallow stony littoral and quantitative characteristics of storm casts on the beaches (mainly decaying Cladophora mats) were shown to be the most appropriate indicators of the environmental quality in the coastal zone of the St. Petersburg Resort District (Orlova et al., 1999a). The volume of these casts averaged several tonnes (in wet mass) per $100 \mathrm{~m}$ of beach shoreline after an ordinary storm in summer. Because mechanical removal of decaying Cladophora mats is expensive and limited to the main beaches, most resort sites along the shoreline are not suitable for recreation during July-August. Decaying organic material on the beaches is an additional source of nutrients for newly developing Cladophora mats in the littoral zone, enhancing the development of macrophyte beds on some beaches.

Changes in the coastal zone in the estuary due to invasions of alien species were discussed in detail in recent reviews by Orlova et al. (1999b) and Panov et al. (1999). Studies of the biodiversity of the coastal waters of the Neva estuary, conducted in 1995-2000 within the framework of the International Program "Gulf of Finland Year 1996" and the Russian State Program "Biodiversity", have shown that several alien species have successfully established in the Neva estuary 
littoral communities. Biological invasions have resulted in the development of new communities in the littoral zone, dominated by the Ponto-Caspian cnidarian Cordylophora caspia and the zebra mussel Dreissena polymorpha, with the New Zealand mud snail Potamopyrgus antipodarum and North American barnacle Balanus improvisus dominating more saline areas, and the Baikalian amphipod Gmelinoides fasciatus and Ponto-Caspian amphipod Pontogammarus robustoides dominating oligosaline and freshwater locations. The Amur sleeper (rotan) Perccottus glenii is currently one of the most abundant fishes in the Neva Bay littoral zone (S. Anatsky, pers. comm.). These alien species are likely to play an important role in the structural and functional organization of coastal zone ecosystems, although at present this role is not well evaluated.

Species of Siberian origin such as G. fasciatus and P. glenii were introduced intentionally to the Neva estuary basin (Panov, 1996; Alimov et al., 1998). These two alien species can be considered a serious threat to the biodiversity of the ecosystem (Panov et al., 1999). A recent invader, G. fasciatus has already replaced the native amphipod Gammarus lacustris in Neva Bay (Panov et al., 1999) and has established dense populations in the littoral zone of the inner estuary, where it co-exists with P. robustoides, an alien amphipod of PontoCaspian origin (Panov, unpubl.). The most serious effect upon the littoral ecosystems of the inner estuary is likely to result from the invasion of D. polymorpha. Dreissena was first found in the Neva estuary in the late 1980s. By 1998 it was well established in littoral communities in the inner estuary, reaching densities up to $150 \mathrm{ind} / \mathrm{m}^{2}$ and biomass $350 \mathrm{~g} / \mathrm{m}^{2}$ (Orlova et al., 1999a, b).

Essential background data on the structure and function of the littoral communities were obtained for Neva Bay during 1982-90 and for the exposed littoral zone of the inner estuary in 1998. These allowed the first official recommendations for the organization of littoral zone monitoring in the Neva estuary to be developed (Balushkina et al., 1999).

In 2000 a new period started in the Neva estuary littoral zone research, including studies conducted within the frameworks of national and international projects. These research efforts focus upon the main factors limiting the development of macrophyte beds and filamentous algae in littoral habitats, along with evaluation of the functional role of alien species. They will provide a scientific basis for the development and implementation of the coastal zone management plans for the Neva estuary. Special research efforts directed toward the assessment of the environmental impact and the development of a management plan for the control of established nuisance species and for the prevention or minimization of the risk of new invasions to the Neva estuary area are needed. These research efforts should include the collection of data on the distribution of alien species in the Neva estuary, the development of a database on alien species in the form of a geographic information system (GIS), analysis of the biology and environmental requirements of target alien species, assessment of the environmental impact of alien species on natural communities, and the development of a cost-effective programme to monitor natural biodiversity and alien species. 


\section{ACKNOWLEDGEMENTS}

The studies were supported by the Russian State Program "Biodiversity", INTAS project No.99-674, Finnish Ministry of Environment, and Maj and Tør Nessling Foundation. Mr. Joseph Ironside (University of Leeds, UK) kindly revised the English text of the manuscript. Authors acknowledge valuable comments of two anonymous referees on the manuscript.

\section{REFERENCES}

Alimov, A. F. (ed.) 1988. Communities of freshwater invertebrates in the macrophyte beds. Proc. Zool. Inst. (Leningrad), 186 (in Russian).

Alimov, A. F., Golubkov, S. M. \& Panov, V. E. 1996. Features of functioning and management strategy for the Neva Estuary ecosystems. In Ecological State of Aquatic Ecosystems in the Neva River Basin (Alimov, A. F. \& Frolov, A. K., eds.), pp. 187-203. St. Petersburg (in Russian).

Alimov, A. F., $\quad$ Panov, V. E., $\quad$ Krylov, P. I., $\quad$ Telesh, I. V., $\quad$ Bychenkov, D. E., Zimin, V. L., Maximov, A. A. \& Filatova, L. A. 1998. The problem of anthropogenic introductions of non-indigenous organisms in the Gulf of Finland basin. In Ecological Situation in St. Petersburg and Leningrad Region in 1997. Analytic Review (Frolov, A. K., ed.), pp 243 248. St. Petersburg (in Russian).

Anon. 1949. Materials for study of benthos in the Neva Bay. Uch. Zap. Leningrad. Univ. Ser. Biol. Nauk, 21, 107-141 (in Russian).

Balushkina, E. V., Finogenova, N. P. \& Slepukhina, T. D. 1996. Changes of zoobenthos characteristics in the water system Lake Ladoga-Neva Bay-eastern Gulf of Finland. In Ecological State of Aquatic Ecosystems in the Neva River Basin (Alimov, A. F. \& Frolov, A. K., eds.), pp. 91-130. St. Petersburg (in Russian).

Balushkina, E. V., Orlova, M. I., Panov, V. E. \& Umnov, A. A. 1999. Hydrobiological monitoring of water systems of St. Petersburg and Leningrad Region. In State Report on Environment Assessment of St. Petersburg and Leningrad Region in 1998, 2, pp. 85-98. St. Petersburg (in Russian).

Belavskaya, A. P. 1987. Characteristics of the nearshore plants. In The Neva Bay: Hydrobiological Investigations (Winberg, G. G. \& Gutelmakher, B. L., eds.), pp. 66-69. Nauka, Leningrad (in Russian).

Finogenova, N. P., $\quad$ Golubkov, S. M., $\quad$ Panov, V. E., $\quad$ Balushkina, E. V., $\quad$ Pankratova, V. J., Lobashova, T. M. \& Pavlov, A. M. 1987. Macrozoobenthos. In The Neva Bay: Hydrobiological Investigations (Winberg, G. G. \& Gutelmakher, B. L., eds.), pp. 111-120. Nauka, Leningrad (in Russian).

Golubkov, S. M., Panov, V. E., Pavlov, A. M. \& Petukhov, V. A. 1987a. Littoral communities of zoobenthos. In The Neva Bay: Hydrobiological Investigations (Winberg, G. G. \& Gutelmakher, B. L., eds.), pp. 164-170. Nauka, Leningrad (in Russian).

Golubkov, S. M., Umnova, L. P., Anokhina, L. E. \& Panov, V. E. 1987b. The processes of production and decomposition in the littoral macrophytes. In The Neva Bay: Hydrobiological Investigations (Winberg, G. G. \& Gutelmakher, B. L., eds.), pp. 70-75. Nauka, Leningrad (in Russian).

Korelyakova, I. L. 1997. Higher Aquatic Plants of Eastern Gulf of Finland. GosNIORKH, St. Petersburg (in Russian). 
Leppänen, J., Pitkänen, H., Savchuk, O., Basova, S., Drabkova, V., Gran, V., Heiskanen, A.-S., Koponen, J., Shpaer, I. \& Silina, N. 1997. Eutrophication and its effects in the Gulf of Finland. In Proceedings of the Final Seminar of the Gulf of Finland Year 1996, March 17-18, 1997 Helsinki (Sarkkula, J., ed.), pp. 31-49. Helsinki.

Orlova, M. I., Anokhina, L. E., Panov, V. E., Nekrasov, A. V. \& Klimentenok, S. N. 1999a. Preliminary environmental state assessment for littoral zone in Resort District of St. Petersburg. BFU Res. Bull., 3, 37-42.

Orlova, M. I., Panov, V. E., Krylov, P. I., Telesh, I. V. \& Khlebovich, V. V. 1999b. Changes in plankton and benthic communities in the eastern Gulf of Finland, associated with biological invasions. Proc. Zool. Inst., 279, 305-325 (in Russian).

Panov, V. E. 1996. Establishment of the Baikalian endemic amphipod Gmelinoides fasciatus in Lake Ladoga. Hydrobiologia, 322, 187-192.

Panov, V. E., Alimov, A. F., Balushkina, E. V. \& Golubkov, S. M. 1997. Functional approach to the evaluation of eutrophication in the Neva Estuary. In Proceedings of the Final Seminar of the Gulf of Finland Year 1996, March 17-18, 1997 Helsinki (Sarkkula, J., ed.), pp. 203213. Helsinki.

Panov, V. E., Krylov, P. I. \& Telesh, I. V. 1999. The St. Petersburg harbour profile. In Initial Risk Assessment of Alien Species in Nordic Coastal Waters (Gollasch, S. \& Leppäkoski, E., eds.). Nord 1999:8, pp. 225-244. Nordic Council of Ministers, Copenhagen.

Pitkänen, H. 1991. Nutrient dynamics and trophic conditions in the eastern Gulf of Finland: The regulatory role of the Neva Estuary. Aqua Fennica, 21, 105-115.

Shishkin, B. A., Nikulina, V. N., Maksimov, A. A. \& Silina, N. I. 1989. Basic Characteristics of the Biota in Upper Gulf of Finland and Its Role in Water Quality Formation. Gidrometeoizdat, Leningrad (in Russian).

\section{LITORAALI UURINGUD NEEVA JÕE SUUDMES: AJALUGU JA PERSPEKTIIVID}

\section{Vadim E. PANOV, Sergei M. GOLUBKOV ja Marina I. ORLOVA}

On antud ülevaade Läänemere suurima estuaari - Neeva jõe suudme - litoraali uuringute ajaloost ning käsitletud sealseid nüüdisaegseid keskkonnaprobleeme, sh. eutrofeerumise ja uute liikide põhjustatud muutusi. Lühidalt on tutvustatud teadusuuringute tulevikku. 